\title{
2. Gender and journalism
}

\author{
PRU GOWARD \\ Federal Sex Discrimination Commissioner, Australia
}

$\mathrm{T}$

HE MEDIA is an important cultural gatekeeper, but not a disinterested one. Inevitably journalists, their interests, backgrounds, intellectual capacity and prejudices shape what they consider we need to know. Even unconsciously they filter what they want us to know about ourselves, each other and the world. This makes the media a major vehicle, although curiously not the only vehicle, for the shaping of public opinion and in particular for the management of our responses to change. The media is also one of the four so-called pillars of democracy, ensuring electors are able to make informed choices as well as engage in public policy debate. Accordingly an effective media represents a diversity of opinion and a range of interests which include the rights and interests and real lives of women as well as the contribution they make to the life of the nation. That's why gender counts in journalism. It is part of diversity.

Diversity also plays a key role in improving decision-making in any leadership group; in the case of the media, where the national interest is frequently at stake, it is arguably even more important that women are present in the editorial and management meetings. Sadly, Australia is still struggling at the top. Despite entry-level journalism being filled with women (when I taught journalism at university level in the 1980s women already made up two thirds of classes) there is a rapid dropping off as they move up the ladder. In newspapers, for example, there is only one major metropolitan newspaper, the Sunday Telegraph, edited by a woman. That is surprising since a large numbers of newspaper lift-out sections are edited by women and the cut-throat magazine market is dominated by women's magazines with female editors. In other words it is not editing competence, or even managerial capacity, that is to blame for this absence of women from top positions on the dailies.

If this were the case in any other industry, it would be widely reported. 


\section{CONTEMPORARY GENDER ISSUES}

By the media. We all seem to know about how tough it is for a woman barrister to get to the Bench or, heaven forbid, the High Court, or what those bastard, male-dominated, political parties do to uppity women, but curiously the media is very shy about putting its own difficulties out for public examination. I fear female journalists are a party to this hegemony. Other male or female-dominated industries have similarly gendered cultures where the dominant group maintains its position "by securing the "spontaneous consent" of subordinate groups' (Strinati, 1995, p. 165). This includes taking on the cultural tone of the dominant gender as if it were common sense and also sexualising the minority 'other' gender. One symptom of hegemony is a code of silence about sexual harassment within a profession. Ask any woman in the male-dominated construction industry about sexual harassment - no, don't ask her that first up, ask her if she ever wears a skirt to work when she goes onto a building site, how often she talks about her private life and whether or not she is married. You'll get the picture.

Ask men in teaching, which is now culturally feminine. Teenage boys tell me they would be accused of paedophilia if they took up primary teaching and that they don't want to be seen as feminine. Compare it with the experiences many of us in journalism had in our younger years in the newsroom, when some bleary eyed, old, male chief-of-staff felt he could say whatever he liked using whatever expletives he liked - and the ones who weren't on the booze occasionally seemed to expect a few sexual favours on the way through.

Another tell-tale sign of hegemony is the absence of a women's ginger group. Usually these are lobby groups but they also provide support for women wishing to network or explore grievances and obstacles collectively. Wherever you look in any other profession or industry grouping, they abound women in accounting, in cardiology, in electrics, in information technology, in law. They seem to have replaced community-based NGOs and they are extremely active. Except in this profession, where it does not seem to be an issue although the facts tell it differently. Australia is unusual in this. There are women's newspaper groups operating in Europe, Canada and the US, in India, China and throughout the developing world.

These groups not only provide mutual support but may also address the deeply vexed issue of the portrayal of women in the media. Sri Lanka has one such group while in China women journalists established a network to monitor portrayal and participation, including a telephone hot line. The Women 
in Television group in Australia has recently produced a stunning booklet on leadership, women and television.

In other countries women's industry associations have established awards, or provided awareness training, or quietly lobbied proprietors to change their employment policies and their portrayal of women. There is very little (public) evidence that Australian journalists, especially in newspapers, consider the representation of women in their ranks deserves special attention. Another aspect of hegemony is of course, denial. I expect to receive some strongly worded letters of criticism from female journalists who have, naturally, encountered none of these problems. And of course, while many individuals may well have passed unscathed, this does not mean the culture is not hostile.

It's true there are some outstanding women journalists leading the way, helping to change culture, and I am intensely grateful to them. Where would we be without Catherine Fox at the Financial Review for example? But these women do not yet represent the culture of their own profession of journalism. Yes, Australian women journalists have a long and proud reputation as tough. They are competitive, combative and persistent, but perhaps their individualistic nature does not foster the development of mutual support groups. And then there are the jokes and cracks from the blokes to withstand. The jokes come easy. Groups like this are derided as sisterhood groups, girls' lunches and clubs for women who can't make it on merit. I've heard all of these before about other women industry groups, often coupled with the contradictory observation that they give women an unfair advantage.

The absence of women at the top of newspapers extends beyond editorial positions. Only 15 percent of all media executives are women. The long hours worked in the profession, the thrill of the deadline and the chase for the scoop tend to exclude those who have other deadlines - supervising year 11 homework or a music lesson. Journalism gives you a ringside seat at the Nature of Life's title fight every day, but the deal is you have to be enthusiastic, even when blood gets splattered. It is also true that the hard drinking, hard living, confronting culture this breeds could well exclude many talented and able people, including women, who wish to live and work differently.

In the heart of a good journalist lives curiosity, insatiable curiosity. Curiosity is an obsessional, reckless trait, and, at present, it is not allowed to go home at $5 \mathrm{pm}$ to cook dinner. I cannot see that part of being a journalist changing, but these days there is at least a limit to the number of staff caught up in 


\section{CONTEMPORARY GENDER ISSUES}

it on any one day. History also takes time to turn. Once women weren't allowed to cover courts, because crime was considered to be too shocking for women to hear, and nice young gels did the social pages not the front pages. It is only in recent times that women have written about sport, and even now you don't see too many female bylines in the sports pages. I have to smile as I write this; when I pointed this out recently I was rewarded with a slap from a weekend paper for not acknowledging how many female sports writers there are now. The trouble is the paper doing the slapping (hegemony again?) had tens of pages of sports coverage with only one female byline - and that was attached to a gossip column!

But as with most other industries, newspapers are changing. And in those changes lie possibilities for women in this industry. Information technology enables stories to be written and filed quickly and many newspapers now go to bed at relatively respectable times. The news cycle is also dominated by the nightly television news, meaning that newsmakers no longer provide stories in the evenings, unless of course it is in the course of an interview. The horrendous hours I remember my newspaper colleagues in the Press Gallery working 20 years ago now seem part of a remote past.

It is also true that more and more women read the front pages of newspapers. Since women have entered the world of work in such large numbers, their demand for knowledge of the world has grown. This is clearly reflected in the growing prominence given to stories covering social policy, health and other issues generally regarded as of more interest to women. Perhaps it also helps explain the disappearance of the semi-naked dolly birds further in.

It is easy for women without children, or for others who have made good in the newspaper industry despite its family unfriendliness, to dismiss these concerns as the whinges of women who couldn't make it. After all, can't anyone succeed in journalism on merit? The truth is that the need for women to accommodate their work and family responsibilities is an enormous constraint on their ambitions and their capacity to contribute to the best of their ability. Putting out a daily newspaper, for example, is not presently possible if you need to leave by six o'clock.

A final thought, based on non-statistically valid observation rather than informed surveys, for the women of Generation Y-qualitatively different, in my view, to all previous generations of women. There is a critical mass now of aspiring, well equipped young women shouting for a place in the 
CONTEMPORARY GENDER ISSUES

world. They are well educated, used to coming top, sexually free and ready to challenge the moral constraints of motherhood, ready to be childless in large numbers if that is what it takes. They will demand hours that work for their families. They will demand jobs that use their talents. They will demand partners who are ready to share. They will take Australia's demographic change, and economic and technological change, and their sweet, emancipated boyfriends, and ride them all the way to Mahogany Row.

Pru Goward became Australia's Federal Sex Discrimination Commissioner for a five-year period in July 2001. Following the introduction of the Age Discrimination Act in 2004, she was also appointed Commissioner Responsible for Age Discrimination. Goward is an economist by training and a broadcaster by practice. She spent 19 years with ABC TV and Radio as a current affairs journalist and later as a political reporter and commentator. In 1997 she became executive director of the Office of the Status of Women in the Department of Prime Minister and Cabinet, serving a number of ministers as well as the Prime Minister.

MelitaGizilis@humanrights.gov.a 